\title{
Rancang Bangun Alat Otomatisasi Mantram Puja Trisandya Menggunakan Mikrokontroler Atmega328
}

\author{
I Nengah Raka Utama ${ }^{1}$, I Gusti Agung Putu Raka Agung ${ }^{2}$, Pratolo Rahardjo ${ }^{3}$
}

\begin{abstract}
Puja Trisandya Mantram chanting, conducted three times a day on daily basis by Hindus in Bali. Usually it is chanted by electronic equipment, which is loudspeakers and operated manually. With technological advances, these activities can be replaced using RTC timer, controlled by microcontroller. This design consists of a microcontroller, Display, Mini MP3Player, Keypad, audio, and Power Supply circuit design. This design will be made so that it can be tested in practice. This tool works automatically by comparing the current time with Puja Trisandya chanting time, so that when a match occurs, the microcontroller will send commands to the Mini mp3 player to play the recorded Trisandya Puja Mantram file that has been stored in micro SD. The result is an LCD (M1602A) capable of displaying letters correspond to words Mantram Trisandya Puja which is the output of the Mini mp3 player in timely mannerwhere as the entire circuit is controlled by microcontroller ATmega328.
\end{abstract}

Intisari- Pengucapan Mantram Puja Trisandya dilaksanakan tiga kali sehari secara rutin oleh umat Hindu di Bali. Biasanya pengucapan memakai peralatan Elektronika dilengkapi dengan pengeras suara dan dioperasikan oleh operator secara manual. Dengan Kemajuan teknologi, aktivitas ini bisa digantikan menggunakan timer RTC yang dikendalikan dengan mikrokontroler. Perancangan rangkaiannya meliputi : Perancangan rangkaian mikrokontroler, Display, Mini MP3 Player, Keypad, Audio , dan Power Supply. Perancangan ini akan direalisasikan sehingga bisa dilakukan pengujian secara nyata. Alat ini berkerja secara otomatis dengan membandingkan jam sekarang dengan waktu pemutaran Mantram Puja Trisandya, apabila terjadi kecocokan data, maka mikrokontroler akan mengirimkan perintah kepada Mini MP3 Player untuk memutar file rekaman Mantram Puja Trisandya yang telah tersimpan pada mikro SD. Dari hasil penelitian didapat LCD (M1602A) mampu menampilkan huruf sesuai dengan kata-kata Mantram Puja Trisandya yang merupakan keluaran dari Mini Mp3 Player dengan tepat waktu. dimana seluruh rangkaian dikendalikan dengan mikrokontroler ATmega328.

Kata Kunci- otomatisasi puja trisandya, mikrokontroler atmega328, rtc ds1302.

${ }^{1}$ Mahasiswa, Teknik Elektro dan Komputer Fakultas Teknik Universitas Udayana, Br. Sengkidu Manggis Karangasem 80871. Indonesia (telp: 081337694123; e-mail: rutama10@yahoo.com)

${ }^{2}$ Dosen, Jurusan Teknik Elektro dan Komputer FakultasTeknik Universitas Udayana, Br. Anggarkasih, Medahan, Blahbatuh, Gianyar 80581 INDONESIA (telp: 081999898301; e-mail: igapraka@yahoo.co.id)

${ }^{3}$ Dosen, Jurusan Teknik Elektro dan Komputer Fakultas Teknik Universitas Udayana, Jln. Tukad Yeh Panan Blok 19 No. 32, Dsn./Br. Jadi Anyar, Ds. Banjar Anyar, Kediri, Tabanan 82123 INDONESIA (telp: 08155770953; e-mail: pratolo@unud.ac.id)

\section{PENDAHULUAN}

Perkembangan teknologi memberikan banyak kemudahan dalam kehidupan umat manusia, sehingga pekerjaan manusia dapat dikerjakan dengan mudah dan tepat waktu. Berbagai macam peralatan rumah tangga hingga peralatan kantor sudah menggunakan alat elektronika sehingga pekerjaan manusia jauh lebih ringan. Salah satu contoh perkembangan teknologi elektronika digunakan sebagai alat untuk mengingatkan umat Hindu untuk melaksanakan Puja Trisandya, adalah Mp3 player atau CD Player. Alat ini biasanya dipasang pada banjar atau pura yang ada di Bali. Mantram Puja Trisandya diperdengarkan menggunakan Mp3 player atau CD Player lengkap dengan Amplifier dan Speaker. Dalam melaksanakan pemutaran Mantram Puja Trisandya ini, masih dikerjakan secara manual yaitu seorang petugas yang telah ditunjuk harus datang ke bale banjar atau pura untuk mengaktifkan Mp3 Player atau CD Player tersebut, agar Puja Trisandya dapat diperdengarkan. Apabila petugas berhalangan, maka pemutaran Mantram Puja Trisandya tersebut tidak terlaksana.

Pada penelitian sebelumnya telah dibuat Rancang Bangun Bel Sekolah Otomatis Berbasis Mikrokontroler AVR ATmega8 [1]. Pada penelitian ini, bel sekolah akan berbunyi secara otomatis sesuai dengan waktu yang telah di atur. Melihat dari penelitian ini maka ada keinginan penulis menerapkan otomatisasi pada pemutaran Mantram Puja Trisandya, dengan menambahkan Amplifier agar suara yang dikeluarkan dari Speaker nanti lebih keras. Selain itu di dalam rancang bangun ini ditambahkan menampilkan teks Mantram Puja Trisandya pada LCD. Dengan menampilkan teks Mantram Puja Trisandya ini dapat membantu generasi muda dalam menghafalkan Mantram Puja Trisandya. Pada penelitian lainnya, Rancang Bangun Sistem Pembacaan Jumlah Konsumsi Air Pelanggan PDAM Berbasis Mikrokontroler Atmega328 Dilengkapi SMS [2], pembacaan waktu dari RTC untuk pengumpulan data telah ditentukan dari awal dan apabila pengguna ingin mengubah waktu pengumpulan data, maka pengguna akan mengalami kesulitan. Maka dari itu pada penelitian ini dibuatkan suatu mekanisme apabila pengguna ingin mengubah waktu pemutaran Mantram Puja Trisandya pengguna dapat mengubahnya dengan mudah.

Pada penelitian ini akan dibuat alat yang dapat memperdengarkan Mantram Puja Trisandya secara otomatis sesuai dengan waktu yang telah ditentukan. Alat ini akan memanfaatkan Microcontroller, RTC, Mini MP3 Player, LCD, Speaker, dan Keypad. Microcontroller yang akan digunakan adalah Microcontroller ATmega328 sebagai pengendali utama. RTC digunakan sebagai penyedia data waktu. Mini MP3 Player digunakan untuk memutar file mp3. Rekaman Mantram Puja Trisandya dengan format mp3, disimpan pada micro SD. Micro SD yang sudah berisi rekaman Puja Trisandya ini, dimasukkan ke Mini MP3 Player. Mini MP3 Player akan memutar file rekaman Mantram Puja Trisandya 
ketika mendapat perintah dari microcontroller. LCD digunakan sebagai output dalam bentuk tulisan, dan Speaker sebagai output dalam bentuk suara. Penelitian ini dilakukan di Banjar Dinas Karangasem, Desa Sengkidu, Kecamatan Manggis, Kabupaten Karangasem, Propinsi Bali.

\section{TinjauAn PustakA}

\section{A. Microcontroller ATmega328}

Microcontroller ATmega328 merupakan Mikrokontroler keluarga AVR 8 bit. Memiliki arsitektur Harvard, yaitu memisahkan memori untuk kode program dan memori untuk data sehingga dapat memaksimalkan kerja dan parallelism.[3]. Instruksi - instruksi dalam memori program dieksekusi dalam satu alur tunggal, dimana pada saat satu instruksi dikerjakan instruksi berikutnya sudah diambil dari memori program. Konsep inilah yang memungkinkan instruksi - instruksi dapat dieksekusi dalam setiap satu siklus clock. Program yang dibuat dengan bahasa pemrograman diupload ke Mikrokontroler, dan kemudian Mikrokontroler akan bekerja sesuai dengan program yang telah dibuat. Microcontroller ATmega328 yang sudah melalui proses burn menjadi modul Arduino Nano [4]. Dapat dilihat pada Gambar 1.

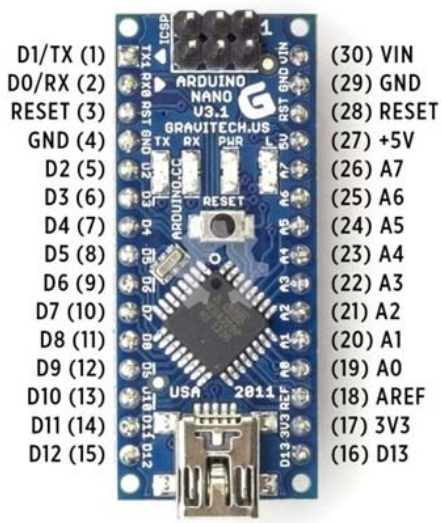

Gambar 1: Microcontroller ATmega328/Arduino Nano

Microcontroller ATmega328/Arduino Nano memiliki 14 pin yang dapat digunakan sebagai input atau output, dengan menggunakan fungsi pinMode(), digitalWrite(), dan digitalRead(), memiliki 8 buah pin analog yang diberi tanda dengan A0, A1, A2, A3, A4,A5, A6, dan A7, masing-masing pin analog tersebut memiliki resolusi 1024 bits. Secara default, pin-pin tersebut diukur dari ground menuju 5 volt. Untuk pin analog A6 dan A7 tidak dapat difungsikan sebagai pin digital. Pin A6 dan A7 hanya dapat difungsikan sebagai pin analog saja. Microcontroller ATmega328/Arduino Nano memiliki sebuah resonator keramik $16 \mathrm{MHz}$, koneksi mini USB tipe-B, colokan power input, ICSP header, dan sebuah tombol reset.

Spesifikasi Microcontroller ATmega328/Arduino Nano :

1. Chip Microcontroller ATmega328

2. Tegangn operasi $5 \mathrm{~V}$

3. Tegangan Input (rekomendasi) $7-12 \mathrm{~V}$

4. Tegangan Input (batasan) $6-20 \mathrm{~V}$

5. Pin I/O Digital 14 buah, 6 diantaranya menyediakan PWM

6. Analog input pin 8 buah

7. Arus DC setiap Pin I/O $40 \mathrm{~mA}$

I Nengah Raka Utama : Rancang Bangun Alat Otomatisasi...
8. Arus DC setiap Pin I/O untuk Pin 3.3V $50 \mathrm{~mA}$

9. Flash Memory $32 \mathrm{~KB}, 2 \mathrm{~KB}$ digunakan oleh bootloader

10. SRAM $2 \mathrm{~KB}$

11. EEPROM $1 \mathrm{~KB}$

12. Clock Speed $16 \mathrm{MHz}$.

\section{B. RTC (Real Time Clock) DS1302}

RTC DS1302 akan difungsikan sebagai komponen utama pada sistem penunjukan tanggal dan waktu, dengan fitur-fitur sebagai berikut :

1. Menghitung waktu mulai detik, menit, jam, tanggal, bulan, tahun, hari dalam minggu dengan kompensasi tahun kabisat sampai tahun 2100.

2. Memory / RAM sebesar 31 byte

3. Single byte atau burst akses

4. Support battery Lithium atau Ni-Cd untuk backup supply

5. Kemampuan Trickle Charge untuk pengisian battery jenis $\mathrm{Ni}-\mathrm{Cd}$.

Komunikasi dari mikrokontroler ke IC DS1302 ini dilakukan melalui antarmuka serial tersinkronisasi yang sederhana melalui 3 jalur I/O: RST (reset), Data, dan SCLK (serial clock). RTC DS1302 memiliki 8 buah pin dan tersedia dalam bentuk 8-pin DIP serta 8-pin SOIC. Konfigurasi dari DS1302 ditunjukkan pada Gambar 2 [5].

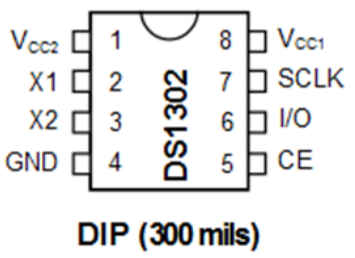

Gambar 2: Diagram pin RTC DS1302

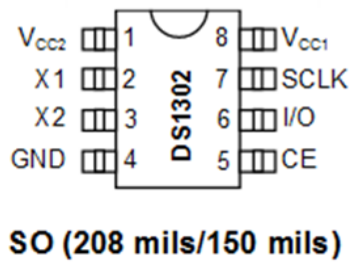

RTC DS1302 merupakan suatu chip IC yang berfungsi menghitung waktu mulai detik, menit, jam, hari, tanggal, bulan, dan tahun dengan akurat dan menjaga atau menyimpan data waktu tersebut secara real time dengan sumber catu daya sendiri dan dinilai cukup akurat sebagai pewaktu (timer) dikarenakan menggunakan osilator kristal eksternal. Sehingga saat perangkat mikrokontroler yang difungsikan untuk mengakses RTC sebagai sumber data waktu dimatikan, data waktu tidak akan hilang selama baterai yang terhubung pada RTC tersebut tidak mati [6].

\section{DFPlayer Mini}

DFPlayer Mini adalah module Sound/music Player yang mendukung beberapa file salah satunya adalah file $\mathrm{mp} 3$ yang umum kita gunakan sebagai format sound file. DFPlayer Mini ini mempunyai 16 pin interface berupa standar DIP pin header pada kedua sisinya [7]. Gambar module DFPlayer mini dapat dilihat pada Gambar 3. 


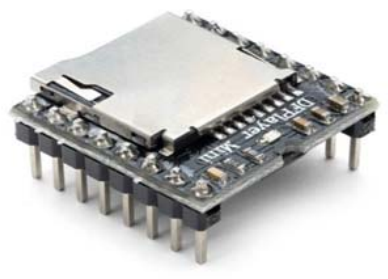

Gambar 3: DFPlayer Mini

\section{LCD (Liquid Crystal Display)}

Display elektronik adalah salah satu komponen elektronika yang berfungsi sebagai tampilan suatu data, baik karakter, huruf ataupun grafik. LCD (Liquid Cristal Display) adalah salah satu jenis display elektronik yang dibuat dengan teknologi CMOS logic yang bekerja dengan tidak menghasilkan cahaya tetapi memantulkan cahaya yang ada di sekelilingnya terhadap front-lit atau mentransmisikan cahaya dari back-lit. LCD (Liquid Cristal Display) berfungsi sebagai penampil data baik dalam bentuk karakter, huruf, angka ataupun grafik [8]. LCD dalam perancangan suatu system yang menggunakan Microcontroller berfungsi untuk menampilkan suatu nilai hasil sensor, menampilkan teks, atau menampilkan menu pada aplikasi mikrokontroler. LCD yang digunakan pada penelitian ini adalah jenis LCD M1602A, merupakan modul LCD dengan tampilan 16 kolom dan 2 baris. LCD M1602A seperti ditunjukkan pada Gambar 4,

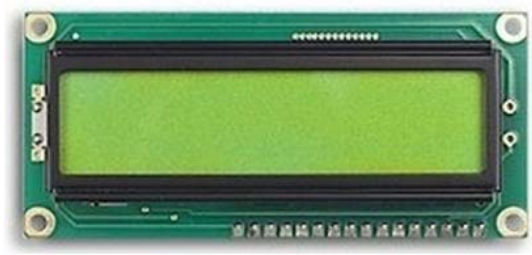

Gambar 4: LCD M1602A

\section{E. Keypad matrix 4x4}

Keypad merupakan komponen elektronik yang digunakan sebagai masukan, disusun dari beberapa tombol/switch dengan teknik matrix. Keypad berfungsi sebagai interface antara perangkat (mesin) elektronik dengan manusia atau dikenal dengan istilah HMI (Human Machine Interface) [9]. Bentuk keypad 4x4 bisa dilihat pada Gambar 5.

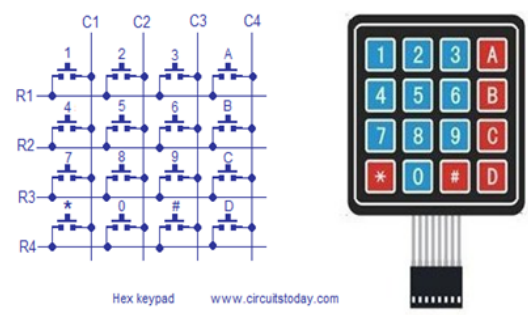

Gambar 5: Matrix Keypad 4x4

Konstruksi matrix keypad $4 \times 4$ terdiri dari 4 baris dan 4 kolom dengan keypad berupa saklar push buton yang diletakan disetiap persilangan kolom dan barisnya.

\section{Metode Penelitian}

Perancangan Alat Otomatisasi Mantram Puja Trisandya Menggunakan Mikrokontroler ATmega328 dibagi menjadi beberapa bagian. Alurnya dapat dilihat pada Gambar 6 .

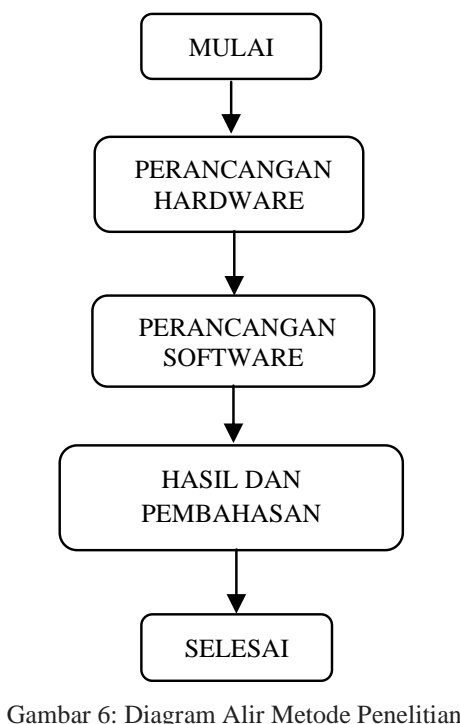

A. Perancangan Hardware

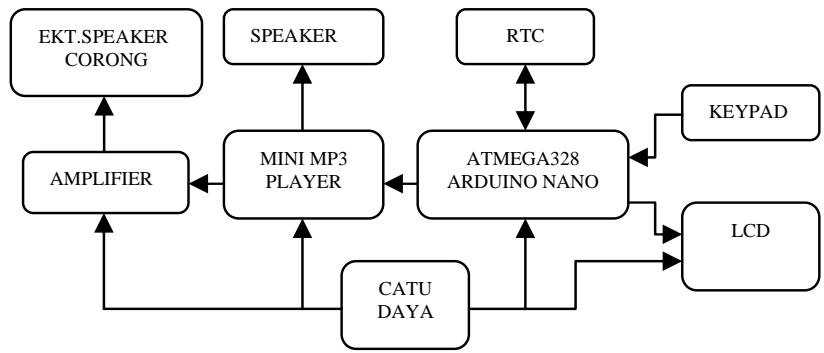

Gambar 7: Diagram Blok Hardware

Perancangan hardware yang dilakukan dalam pembuatan Rancang Bangun Alat Otomatisasi Mantram Puja Trisandya Menggunakan Mikrokontroler ATmega328/Arduino Nano adalah sebagai berikut:

1. Perancangan rangkaian Catu Daya

2. perancangan rangkaian RTC

3. perancangan rangkaian Display

4. perancangan rangkaian Mini MP3 Player

5. perancangan rangkaian System Audio

6. perancangan rangkaian Keypad

7. perancangan rangkaian keseluruhan

Perancangan rangkaian hardware menggunakan program Proteus 8 Professional. Hasil perancangan keseluruhan rangkaian dapat dilihat pada Gambar 8. 
DOI: https://doi.org/10.24843/MITE.2018.v17i01.P11

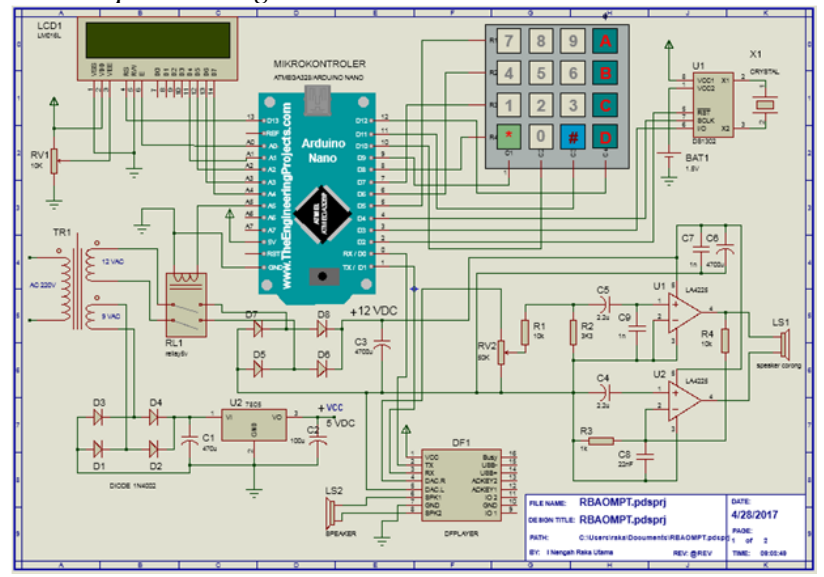

Gambar 8: Perancangan Keseluruhan Rangkaian

Cara kerja peralatan ini adalah sebagai berikut. Seluruh rangkaian dikontrol oleh mikrokontroler Atmega328/Arduino Nano. RTC DS1302 menyediakan data waktu untuk ditampilkan pada LCD. Ketika waktu menunjukkan pukul 06.00, 12.00, dan 18.00, mikrokontroler akan memberi perintah untuk mengaktifkan Mini MP3 Player sehinggga file rekaman Mantram Puja Trisandya dapat diperdengarkan melalui speaker. Mikrokontroler juga akan memberi perintah untuk mengaktifkan rellay. Dengan aktifnya rellay, amplifier mendapat supply tegangan, sehingga amplifier menjadi on dan suara yang dihasilkan melalui speaker corong menjadi lebih keras. Apabila file rekaman Mantram Puja Trisandya telah selesai diperdengarkan, maka mikrokontroler akan memberi perintah untuk me-nonaktif-kan rellay sehingga amplifier menjadi off. Pengaturan waktu dapat dilakukan melalui penekanan tombol pada keypad.

\section{B. Perancangan Software}

Perancangan software untuk memprogram mikrokontroler ATmega328/Arduino Nano menggunakan aplikasi IDE (Integrated Development Environment) merupakan aplikasi bawaan dari Arduino. Aplikasi ini berguna untuk membuat, membuka, dan mengedit source code Arduino. Source code Arduino biasa di sebut dengan Sketch. Sketch merupakan source code yang berisi logika dan algoritma yang akan diupload ke dalam IC microcontroller ATmega328/Arduino Nano.

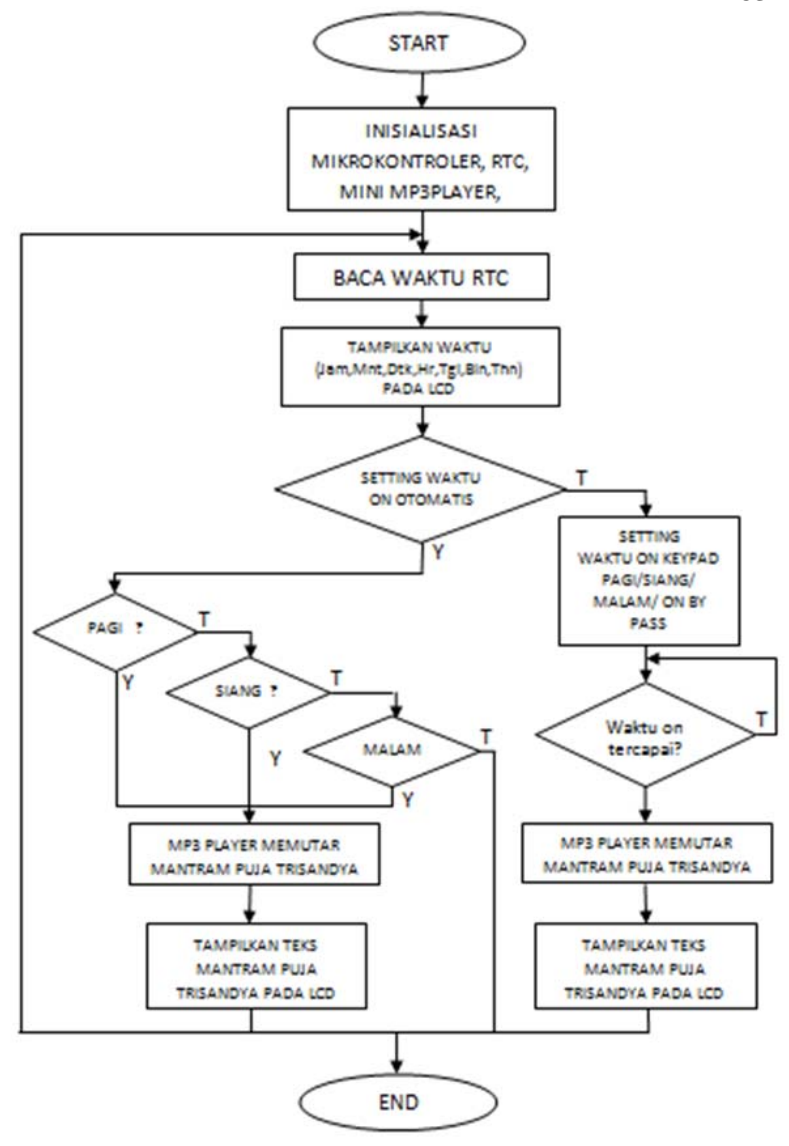

Gambar 9: flowchart Perancangan Software

Diagram alir (flowchart) program dari Alat Otomatisasi Mantram Puja Trisandya, ditunjukkan pada Gambar 9. Pertama adalah inisialisasi mikrokontroler Atmega328/Arduino Nano, RTC, LCD, mini MP3 Player, dan siap untuk beroperasi. Proses looping dimulai dari pembacaan waktu pada RTC. Dilanjutkan dengan menampilkan waktu tersebut pada LCD. Apabila state logic tidak pada penyetingan waktu pemutaran file Mantram Puja Trisandya, maka state dilanjutkan dengan mecocokkan hasil pembacaan waktu RTC dengan salah satu waktu pemutaran Puja Trisandya yang telah ditentukan, jika sesuai maka alat akan memutarkan file Mantram Puja Trisandya. Setelah pemutaran file Mantram Puja Trisandya selesai, maka alur akan kembali ke proses awal looping yaitu pembacaan waktu RTC. Selanjutnya apabila state logic saat ini berada pada penyetingan waktu pemutaran file Mantram Puja Trisandya maka logic akan menerima masukan untuk mengubah waktu pemutaran file Mantram Puja Trisandya, setelah perubahan tersimpan maka alur akan kembali ke proses awal looping. Looping ini akan berjalan terus sampai alat dimatika.

\section{HASIL DAN PEMBAHASAN}

p-ISSN:1693 - 2951; e-ISSN: 2503-2372

I Nengah Raka Utama : Rancang Bangun Alat Otomatisasi...

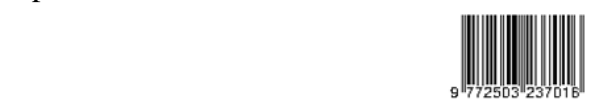


A. Realisasi Hasil Perancangan Alat

Realisasi Rancang Bangun Alat Otomatisasi Mantram Puja Trisandya menggunakan Mikrokontroler ATmega328. ATmega328/Arduino Nano, dapat dilihat seperti Gambar 10 sampai dengan Gambar 10

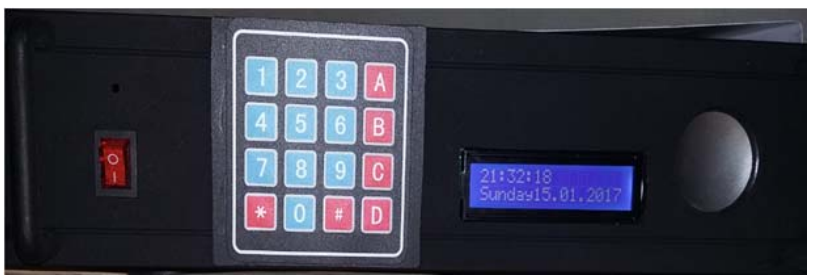

Gambar 10: Tampak Depan

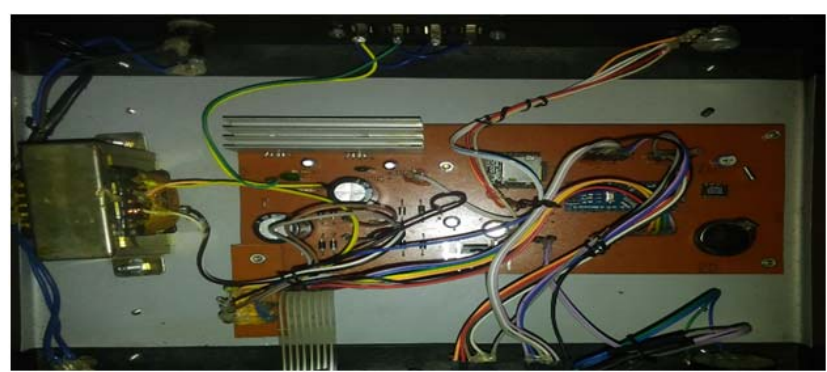

Gambar 11: Tampak Atas

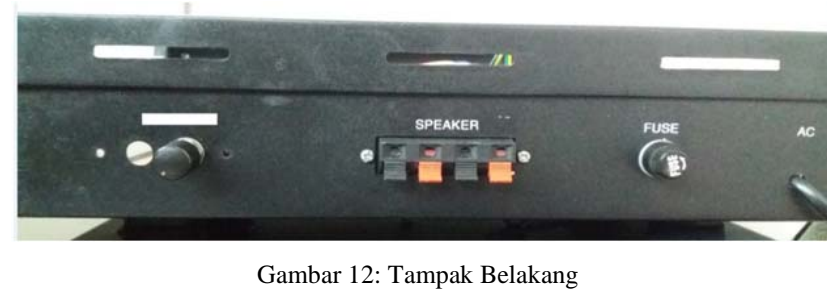

B. Pengujian dan Pembahasan Konsumsi Daya Listrik

Pengujian konsumsi daya listrik bertujuan untuk mengetahui besarnya konsumsi daya dari Alat Otomatisasi Mantram Puja Trisandya yang telah direalisasikan. Pengujian konsumsi daya listrik meliputi pengujian konsumsi daya listrik pada sumber tegangan PLN, pengujian konsumsi daya listrik pada rangkaian utama, dan pengujian daya listrik pada setiap komponen (RTC, LCD, Mini MP3 Player, dan Mikrokontroler).

1. Pengujian Konsumsi Daya Listrik Pada Sumber Tegangan PLN

Pengujian konsumsi daya listrik pada sumber tegangan PLN dilakukan dengan pengukuran tegangan, arus, daya, dan energi pada sumber tegangan PLN sebelum rangkaian utama, dengan menggunakan alat ukur digital multy-function meter. Diagram blok pengujian konsumsi daya listrik pada sumber tegangan PLN dapat ditunjukkan seperti Gambar 13.

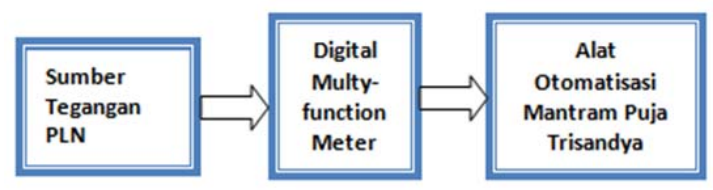

Gambar 13: Diagram Blok Pengujian Konsumsi Daya Listrik pada Sumber Tegangan PLN

Hasil pengukuran konsumsi daya pada sumber tegangan PLN ditunjukkan pada Tabel 1.

TABEL I

PENGUJIAN KONSUMSI DAYA LISTRIK

\begin{tabular}{|c|c|c|c|c|c|c|}
\hline No & $\begin{array}{c}\text { Alat } \\
\text { Dalam } \\
\text { Kondisi }\end{array}$ & $\begin{array}{c}\text { Waktu } \\
\text { (Jam) }\end{array}$ & $\begin{array}{c}\text { Tegangan } \\
\text { (VAC) }\end{array}$ & $\begin{array}{c}\text { Arus } \\
\text { (A) }\end{array}$ & $\begin{array}{c}\text { Daya } \\
\text { (W) }\end{array}$ & $\begin{array}{c}\text { Energi } \\
\text { (Wh) }\end{array}$ \\
\hline 1 & $\begin{array}{c}\text { On } \\
\text { Trisandya }\end{array}$ & 1 & 215 & 0.03 & 3.1 & 3 \\
\hline 2 & Stanby & 1 & 217 & 0.03 & 3.2 & 3 \\
\hline 3 & Stanby & 2 & 222 & 0.03 & 3.3 & 6 \\
\hline 4 & Stanby & 3 & 223 & 0.03 & 3.3 & 9 \\
\hline
\end{tabular}

Dalam satu hari, kondisi alat memutar file rekaman Mantram Puja Trisandya sebanyak 3 kali, berarti terdapat 3 jam rentang waktu untuk kondisi On Trisandya, dan terdapat 21 jam alat dalam kondisi stanby. Pada pengukuran kondisi stanby sesuai Tabel 1, dengan rentang waktu 1 jam, 2 jam, dan 3 jam, didapatkan pengukuran yang konstan, yaitu pada rentang waktu 1 jam dengan konsumsi energi $3 \mathrm{~W} / \mathrm{h}$. Rentang waktu 2 jam dengan konsumsi energi $6 \mathrm{~W} / \mathrm{h}$, dan rentang waktu 3 jam dengan konsumsi energi $9 \mathrm{~W} / \mathrm{h}$, dengan rata-rata konsumsi energi perjam adalah $3 \mathrm{~W} / \mathrm{h}$. Perhitungan konsumsi daya pada kondisi On Trisandya adalah 3 jam x $3 \mathrm{~W} / \mathrm{h}=9 \mathrm{~W} / \mathrm{h}$, dan perhitungan konsumsi daya pada kondisi stanby adalah 21 jam x $3 \mathrm{~W} / \mathrm{h}=63 \mathrm{~W} / \mathrm{h}$. Jadi dalam sehari konsumsi energi adalah $72 \mathrm{~W} / \mathrm{h}$. Jika diakumulasikan waktu satu bulan jumlah konsumsi energi sebesar 2,16 sehinggan total pembayaran dalam satu bulan untuk daya yang terpasang 900 VA dengan harga per kWh Rp. 495 (PerMen ESDM No.28, 2016) [10] adalah sebesar Rp. 1.069.

2. Pengujian Konsumsi Daya Listrik Pada Rangkaian Utama

Pengujian konsumsi daya listrik pada rangkaian utama dilakukan dengan mengukur nilai tegangan dan arus setelah rangkaian catu daya/voltage regulator. Diagram blok dari pengujian konsumsi daya listrik pada rangkaian utama ditunjukkan pada Gambar 14.

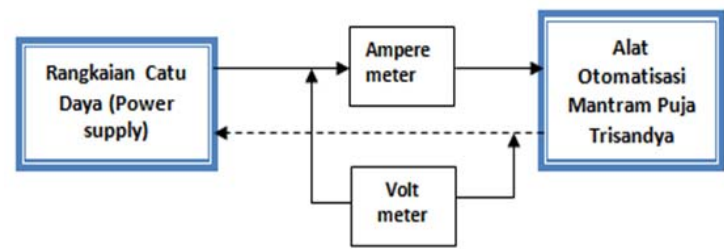

Gambar 14: Diagram Blok Pengujian Konsumsi Daya Listrik pada Rangkaian Utama

Pengukuran tegangan dan arus dilakukan menggunakan alat ukur digital multy-meter pada output rangkaian catu daya/volage regulator 5 VDC dan 12 VDC pada kondisi dengan beban dan tanpa beban. Hasil pengujian konsumsi daya pada rangkaian utama ditunjukkan pada Tabel 2. 
Majalah Ilmiah Teknologi Elektro, Vol. 17, No. 1,Januari -April 2018

DOI: https://doi.org/10.24843/MITE.2018.v17i01.P11 TABEL II

PENGUJIAN KONSUMSI DAYA LISTRIK PADA RANGKAIAN UTAMA

\begin{tabular}{|c|c|c|c|c|c|}
\hline \multirow{2}{*}{ No } & \multirow{2}{*}{$\begin{array}{c}\text { Catu Daya } \\
\text { (Voltage } \\
\text { Regulator) }\end{array}$} & \multicolumn{2}{|c|}{$\begin{array}{c}\text { Tegangan } \\
\text { (VDC) }\end{array}$} & \multicolumn{2}{|c|}{$\begin{array}{c}\text { Arus } \\
\text { (Ampere) }\end{array}$} \\
\cline { 3 - 6 } & Dengan & $\begin{array}{c}\text { Tanpa } \\
\text { Beban }\end{array}$ & $\begin{array}{c}\text { Dengan } \\
\text { Beban }\end{array}$ & $\begin{array}{c}\text { Tanpa } \\
\text { Beban }\end{array}$ \\
\hline 1 & 5 VDC & 4.98 & 5.0 & 0.1177 & - \\
\hline 2 & 12 DCV & 12.27 & 12.30 & 0.133 & - \\
\hline
\end{tabular}

Berdasarkan Tabel 2, hasil pengukuran tegangan pada output rangkaian catu daya/voltage regulator LM7805 dengan beban, menunjukkan nilai 4,98 volt, dan pengukuran arus listrik menunjukan nilai $117,7 \mathrm{~m}$ A atau 0.1177 A. Hasil pengukuran ini sudah sesuai dengan yang diharapkan walaupun ada penyimpangan tegangan. Toleransi penyimpangan tegangan keluaran dari IC LM7805 yang diijinkan adalah kurang lebih 4\% [11]. Yaitu dengan batas keluaran 4,8 - 5,2 Volt. Hasil pengukuran tegangan pada output catu daya untuk tegangan input Amplifier menunjukkan nilai 12,27 volt. Ic Power Amplifier LA 4225 yang digunakan pada penelitian ini, membutuhkan tegangan operating voltage range 5 hingga $22 \mathrm{VDC}$, dengan recommended supply voltage 13,2 VDC [12]. Hasil pengukuran arus listrik pada output catu daya untuk input Amplifier menunjukkan nilai 117,7 mili ampere atau 0,1177 ampere. Sesuai data sheet Ic Power Amplifier LA 4225 ini, membutuhkan arus diantara 65 hingga $130 \mathrm{~mA}$, dengan maximum output current $3.3 \mathrm{~A}$ [12]. Tegangan dan arus yang dihasilkan pada rangkaian catu daya/voltage regulator sudah sesuai dengan perencanaan.

3. Pengujian Konsumsi Daya Listrik Pada Setiap Komponen (RTC, LCD, Mini MP3 Player, Mikrokontroler)

Pengujian konsumsi daya listrik pada setiap komponen dilakukan dengan mengukur nilai tegangan dan arus pada pin DC input di setiap komponen (RTC, LCD, Mini MP3 Player, Mikrokontroler). Hasil pengujian konsumsi daya pada setiap komponen (RTC, LCD, Mini MP3 Player, Mikrokontroler) ditunjukkan pada Tabel 3.

TABEL III

PENGUJIAN KONSUMSI DAYA LISTRIK PADA SETIAP KOMPNEN

\begin{tabular}{|c|c|c|c|}
\hline No & Komponen & $\begin{array}{c}\text { Tegangan } \\
\text { (VDC) }\end{array}$ & $\begin{array}{c}\text { Arus } \\
\text { (mA) }\end{array}$ \\
\hline 1 & RTC & 4.98 & 0.03 \\
\hline 2 & LCD & 4.98 & 0.745 \\
\hline 3 & Mini MP3 Player & 4.98 & 42.6 \\
\hline 4 & Mikrokontrol & 4.98 & 74.3 \\
\hline
\end{tabular}

Berdasarkan Tabel 3, tegangan pada pin input RTC, LCD, Mini MP3 Player, dan Mikrokontroler adalah 4.98 VDC, tegangan ini merupakan tegangan VCC. Pengukuran arus listrik yang mengalir pada pin DC input Mikrokontroler didapatkan nilai arus yang paling besar yaitu $74.3 \mathrm{~mA}$ atau 0.0743 A, sedangkan untuk RTC didapatkan pengukuran arus paling paling kecil yaitu $0.03 \mathrm{~mA}$ atau $30 \mu \mathrm{A}$. Jumlah arus keseluruhan pada tegangan 5 volt adalah $117.675 \mathrm{~mA}$.

\section{Pengujian Dan Pembahasan Alat Secara Keseluruhan}

Pengujian Alat Otomatisasi Mantram Puja Trisandya secara keseluruhan bertujuan untuk mengetahui apakah alat yang direncanakan dapat bekerja dengan baik sesuai dengan I Nengah Raka Utama : Rancang Bangun Alat Otomatisasi... yang direncanakan. Berdasarkan perencanaan yang telah dibuat, alat ini bekerja secara otomatis memutar file Mantram Puja Trisandya pada Pagi (06.00), Siang (12.00), dan Malam hari (18.00). dan waktu pemutaran Mantram Puja Trisandya ini dapat diatur sesuai dengan waktu yang diinginkan.

\section{KESIMPULAN DAN SARAN}

Adapun simpulan dari penelitian ini adalah rangkaian Display (LCD M1602A) sudah mampu menampilkan huruf sesuai dengan kata-kata Mantram Puja Trisandya yang merupakan keluaran audio dari Mini MP3 Player. RTC (DS1302) sudah mampu menghasilkanan waktu yang sama dengan waktu sekarang (Real Time Clock) sehingga tampilan pada LCD dan jam pembanding sudah sama. Keypad sudah dapat digunakan untuk mengubah data waktu pemutaran Mantram Puja Trisandya. Peralatan ini sudah dapat memutar file Mantram Puja Trisandya sesuai dengan waktu yang sebenarnya, yaitu tiga kali sehari pada jam 06.00, 12.00, dan 18.00 wita.

Adapun saran yang dapat diberikan untuk penelitian selanjutnya adalah penambahan program dan file rekaman untuk pemutaran pesan atau pengumuman yang bersifat rutinitas. Perlu penambahan power supply cadangan untuk keseluruhan rangkaian, karena pada penelitian kali ini hanya rangkaian RTC saja yang memiliki power supply cadangan.

\section{REFERENSI}

[1] Agung I. G. A. P., Janardana I. G. N., and Ardiansyah F., "Rancang Bangun Bel Sekolah Otomatis Berbasis Mikrokontroler AVR ATMEGA8”. (2013). [Online]. Available: https://ojs.unud.ac.id/index.php/JTE/article/view/5562

[2] Suardiana I. M. N., Agung I. G. A. P., and Rahardjo P. (2016) [Online]. Available: https://ojs.unud.ac.id/index.php/JTE/article/view/21576

[3] Dhan. ATmega328. (2014). [Online]. Available: http://ramdhoninterface.blogspot.co.id/2014/10/atmega328-diagram-blok.html.

[4] Archtz. "Mengenal Arduino Nano". (2015). [Online]. Available: https://archtz.wordpress.com/2015/05/12/mengenal-arduino-nano/

[5] “DS1302 Datasheet”. Maxim Integrated. [Online]. Available: http://www.alldatasheet.com/datasheetpdf/pdf/254790/MAXIM/DS1302.html

[6] Ratna P. “Tutorial Arduino akses RTC modul DS1302 dengan mudah”. (2017). [Online]. Available: http://www.ngarep.net/tutorial-arduinoakses-rtc-ds1302/

[7] “DFPlayer Mini Datasheet”.Dfrobot. [Online]. Available: https:// www.dfrobot.com/wiki/index.php/DFPlayer_Mini_SKU: DFR0299

[8] Purnama. "Elektronika Dasar”. (2013). [Online]. Available: http://elektronika-dasar.web.id/lcd-liquid-cristal-display/

[9] Purnama. "Elektronika Dasar”. (2013). [Online]. Available: http://elektronika-dasar.web.id/matrix-keypad-4x4-untuk-mikrokontroler/

[10] Sirajudin. "Tentang tarif tenaga listrik yang disediakan oleh PT. PLN". (2017). [Online]. Available: http://www.slideshare.net/MPartII/Permenesdm-no-28-tahun-2016

[11] “LM7805 Datasheet”. Dallas, [Online]. Available: https://www.sparkfun.com/datasheets/Components/LM7805.pdf

[12] “LA4225 Datasheet”. Sanyo, [Online]. Available: http://www. alldatasheet.com/datasheet-pdf/pdf/941839/SANYO/LA4225.html 